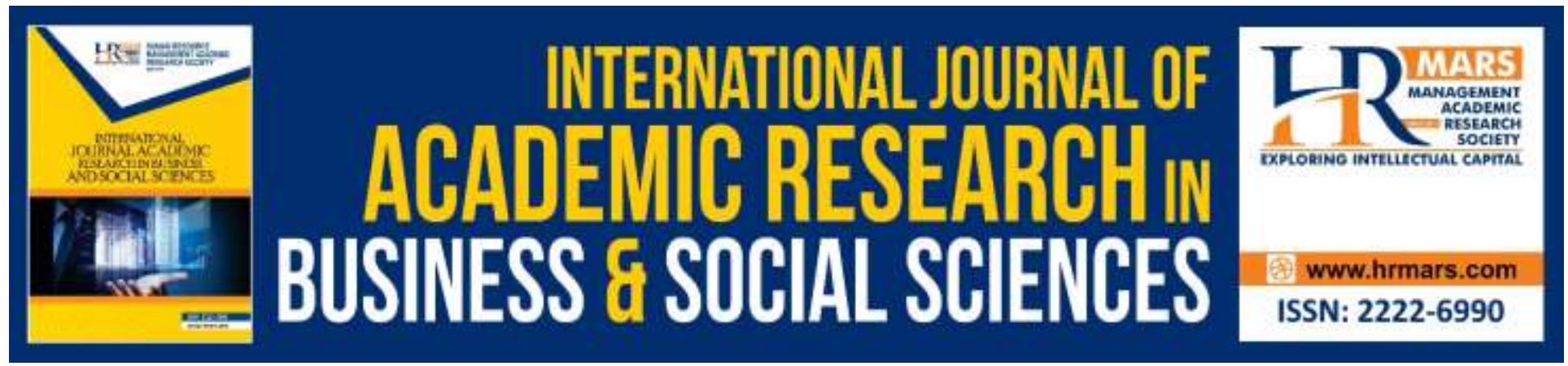

\title{
The Exploration of Job Demands on Engagement at a Transforming Tertiary institution in Namibia
}

Elaine January -Enkali and Nambira Geoffrey

To Link this Article: http://dx.doi.org/10.6007/IJARBSS/v9-i10/6554

DOI: 10.6007/IJARBSS/v9-i10/6554

Received: 19 August 2019, Revised: 30 August 2019, Accepted: 04 Oct 2019

Published Online: 29 Oct 2019

In-Text Citation: (Enkali \& Geoffrey, 2019)

To Cite this Article: Enkali, E. J., \& Geoffrey, N. (2019). The exploration of job demands on engagement at a transforming tertiary institution in Namibia. International Journal of Academic Research in Business and Social Sciences, 9(10), 373-384.

Copyright: (C) 2019 The Author(s)

Published by Human Resource Management Academic Research Society (www.hrmars.com)

This article is published under the Creative Commons Attribution (CC BY 4.0) license. Anyone may reproduce, distribute, translate and create derivative works of this article (for both commercial and non-commercial purposes), subject to full attribution to the original publication and authors. The full terms of this license may be seen

at: $\underline{\text { http://creativecommons.org/licences/by/4.0/legalcode }}$

Vol. 9, No. 10, 2019, Pg. 373 - 384

http://hrmars.com/index.php/pages/detail/IJARBSS

JOURNAL HOMEPAGE

Full Terms \& Conditions of access and use can be found at http://hrmars.com/index.php/pages/detail/publication-ethics 


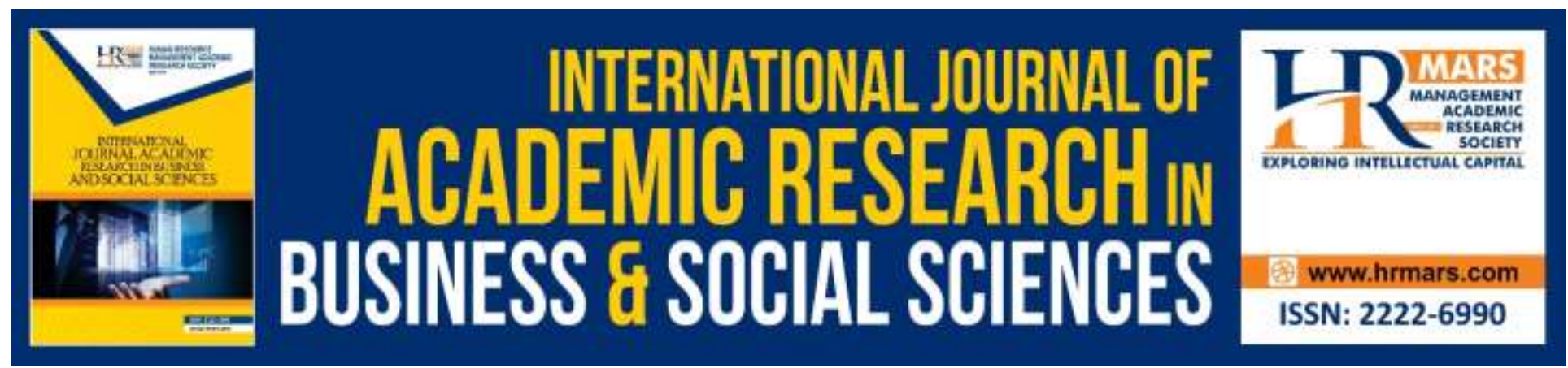

\title{
The Exploration of Job Demands on Engagement at a Transforming Tertiary institution in Namibia
}

\author{
Ms. Elaine January -Enkali and Dr. Nambira Geoffrey \\ Namibia University of Science and Technology \\ Department of Management
}

\begin{abstract}
In a period of transformation and change at NUST, where full university status has been accorded to the institution, academic staff are increasingly challenged to perform better regarding issues such as new demands in course design and delivery, innovative teaching techniques, the integration of technology in teaching and learning, and higher research output, amongst others. The awareness of higher work engagement amongst academics should thus be particularly appealing to the higher education system in Namibia. However, when the environment is not conducive and job demands are high, staff members may find it difficult to become fully engage in their work. The objective of this study was to investigate the effect of job demands on the work engagement levels of academic staff at NUST. To achieve the aims of the study a selfadministered questionnaire was administered to full-time academic staff members across the six faculties and a total of 201 academic staff members participated in the study. Inferential analysis such as chi-square and correlation analysis were used to determine the strength of the relationships between engagement and job demands. The results indicated that job demands, specifically the work situations and emotions, have an impact on the engagement levels of the academic staff. Since high job demands are directly linked to burnout, it is recommended that the institution develop intervention strategies specifically related to the work situation and coping strategies of academic staff.
\end{abstract}

Keywords: Employee Engagement, Academic Staff, Job Demands, Transformation.

\section{Introduction}

The higher education system has been subjected to many changes during the past few years. Rothmann and Jordaan (2006) reported on several problems in the South African higher education system, such as inequalities and misrepresentation of the system, poorly prepared students, and declining government subsidy. This may contribute to an overload of job demands and an undersupply of response capabilities in higher education. Similar challenges are also observed in the Namibian context. The study of work engagement amongst academic staff at the 
institution may, therefore, reveal information on work engagement and aspects in the work environment, specifically, job demands, which may hinder full engagement of staff. Schaufeli and Bakker (2004, p 296) refer to job demands as "physical, psychological, social, or organizational aspects of a job that require sustained physical and /or psychological (i.e., cognitive or emotional) effort and are therefore associated with certain physiological and psychological costs." They, however, argue that although job demands are not always regarded as negative, they are potential job stressors, especially when meeting demands that require increased effort which is associated with high costs. These job demands can elicit negative responses such as depression, anxiety, and burnout.

\section{Research Problem Statement}

Despite this knowledge of the importance of creating work environments that engage workers, the current climate at higher education institutions in terms of job demands is rather gloomy. High job demands can have a negative effect on employee performance and previous research indicated that the academic world is no exception in this regard. Arokiasamy, Ismael, Ahmad and Othman (2009) assert that the challenges academics are confronted with are numerous and include matters such as promotion issues, use of the latest technology, multi-task responsibilities, uncertain structures, funding issues, emphasis on research without proper facilities and remuneration. A similar study carried out by Bezuidenhout and Bezuidenhout (2014) indicates the same trend in South African universities. Challenges include globalisation of the higher education system, digital transformation in both contact and distance learning institutions, a shortage of academics with doctoral degrees and the increased use of social media in education. Furthermore, there is a very high student to lecturer ratio, an extremely high student to postgraduate supervisor ratio, decreased resources, and increasingly high expectations and demands by faculty, students and parents. The lines between work time and personal life are also increasingly blurred. The same challenges are observed at NUST which can confirm the idea that job demands are relatively high for academics. The study was prompted by the fact that the relationship between job demands and work engagement of academic staff members were not previously investigated at NUST.

\section{Research Questions and Objectives}

The leading research question was 'To what extent does job demands influence the engagement levels of academics at NUST? The main research objective following the research question was to determine the relationship between job demands and work engagement levels of NUST academics.

\section{Research Hypothesis}

To achieve the research objectives, the following hypotheses were formulated:

$\mathrm{H}_{0}$ : There exists no relationship between job demands and engagement levels.

$\mathrm{H}_{1}$ : There exists a relationship between job demands and engagement levels. 


\section{Literature Review}

\section{Definition and Elements of Job Demands}

Job demands refer to as those physical, psychological, social, or organisational aspects of a job that require sustained physical and /or psychological (i.e., cognitive or emotional) effort and are thus associated with certain physiological and psychological costs. Rothmann, Strydom, and Mosterd (2006) highlighted overload, job insecurity, advancement, growth opportunities and organisational support as potential job demand elements. Overload refers to the amount of work, that is, mental and emotional workload. Job insecurity refers to uncertainty about the future of the job. They further describe growth opportunities as enough variety, prospects to develop and independence, whereas advancement means moving forward in the company in terms of remuneration, career opportunities, and training. Lastly, they mention organisational support which refers to supervisory relationships, transparency, communication and social support from colleagues.

\section{The Impact of Job Demands on Work Engagement}

High job demands can have a negative effect on employee performance and previous research indicated that the academic world is no exception in this regard. Previous studies indicate the detrimental impact of high job demands on work engagement. A study on the job demands, job resources and work engagement of managers at a mine in South Africa by Rothmann and Joubert (2007) revealed that high job demands and lack of job resources increase levels of burnout. They indicated that job demands, because of a high workload and job insecurity, combined with a lack of job resources such as insufficient organizational support and opportunities for advancement, contributed to a high level of exhaustion in their study. This is confirmed by Barkhuizen, Rothmann and van der Vijver (2013) in a study on burnout and work engagement of academics in higher education institutions which found that exhaustion and burnout are a direct response to job demands.

In contrast, it seems that there is an interesting aspect of job demands. Previous research indicates that high job demands can increase work engagement, especially when job resources are low. Research by Rothmann and Jordaan (2006) on job demands, job resources and the work engagement of academic staff in South African higher education institutions shows that job demands contribute to the dedication of academics when organisational support is low.

This view is echoed by Bakker, Van Veldhoven and Xanthpoulou (2010) who tested the JobDemands Resources Model. The findings of their research indicate that employees thrive on high job demands when an insufficient amount of job resources are available. They argue that high job demands seem to not be problematic but rather induce employees to make full use of available resources, which results in high levels of task enjoyment and organisational commitment. It can thus be concluded that high job demands should not always be regarded as a negative factor but can, in some instances, help employees to utilise their existing resources in a more creative manner. 


\section{Measurement of Job Demands}

Bakker (2014) developed the English version of the Job Demands-Resources Questionnaire (JD$\mathrm{R}$ Questionnaire). The questionnaire can be used to establish the predictors of work engagement and job performance specifically in terms of job resources and job demands. Work engagement is measured in three dimensions, namely vigour, dedication, and absorption. Job demands are measured by work pressure, cognitive demands, emotional demands, role conflict, and hassles. Rothmann et al (2006) also developed a questionnaire to investigate job demands and resources, conceptualized by the Job Demands-Resources Model. (JD-R Model) This questionnaire was used in a study on factors associated with employee engagement in South Africa and measured aspects such as work overload, job insecurity, growth opportunities, advancement, and organizational support

\section{Theoretical Framework}

\section{Conservation of Resources (COR Theory)}

According to Hobfall and Freedy (as cited by Rothmann and Joubert, 2007), burnout will develop when resources that are valued by employees are lost or are inadequate to meet demands. Resources, in this context, refer to aspects such as control, participation in decision-making and autonomy, whereas demands include role ambiguity, work pressure, and workload. They, therefore, conclude that a work environment which is excessively demanding normally also offers insufficient resources.

\section{The Job Demands -Resources Model of Bakker and Demerouti}

Bakker and Demerouti (2008) developed a work engagement model based on assumptions of the Job Demands-Resources Theory (JD-R Theory). The first assumption states that job resources, such as social support, performance feedback, skill variety, and autonomy, will start a motivational process which will lead to work engagement and result in higher performance. Secondly, job resources will become more prominent when employees are confronted with high job demands such as high workload, emotional and mental demands.

\section{Research Methodology}

The study was conducted from a positivistic paradigm. According to Kotzé (2011), this paradigm can be modelled on the natural science approach. It strives to achieve objective knowledge that can, in the end, be used to ascertain cause-and-effect relationships. The positivistic paradigm was appropriate to the study as it attempts to find a relationship between constructs mentioned for this study and will make use of an objective measurement instrument for the data gathering and analysis procedures.

This study employed a descriptive research design. Basic descriptive statistics were used to describe the quantitative data, in terms of deriving conclusions and distributions from the questionnaire. Babbie and Mouton (2011) state that when the descriptive research approach is employed, it is used to systematically describe a problem, situation, phenomenon or attitude towards a specific issue. 
Survey research, cross-sectional research design. Denscombe (2010) states that surveys are appropriate when dealing with specific issues and when researchers know beforehand which factors are important and the kind of information needed. Survey design is the economy of the design and the fast turnaround in data collection. Cross-sectional studies are quick, easy and relatively cheap to perform and are often based on a questionnaire survey (Sedgwick, 2014). Furthermore, a cross-sectional design is a method that was used to study academic engagement and job demands. A self-administered closed-ended questionnaire, namely, the JD-R questionnaire was used in the study.

\section{Target Population and Sampling}

Neuman (2011) describes a population as the intangible idea of a big group of numerous cases from which a researcher draws a sample and of which results from the sample are generalized. In this study, the population was the full-time academic staff of NUST. The part-time academics were excluded from the study because they work on a contract basis with different employment conditions. At the time of the study, the number of full-time academic staff members was four hundred and twenty. Participants included staff members from all hierarchical levels ranging from Deans, Deputy Deans, Heads of Departments, and Deputy Heads of Departments, Senior Lecturers, Lecturers, and Junior Lecturers. All six faculties, namely the Faculty of Computing and Informatics, Faculty of Engineering, Faculty of Health and Applied Sciences, Faculty of Human Sciences, Faculty of Management Sciences and Faculty of Natural Resources and Spatial Sciences, were included in the study.

The study employed a probability specifically simple random sampling technique. A list of all full-time academic staff members which was obtained from the Human Resources Department at NUST was used as a sampling frame for this study. The sample size was determined under the Simple Random Sample (SRS) design which was 201. The sample size made an allowance for the non-responding staff members.

\section{The Research Instruments}

The engagement and job demand sections of the Job Demands-Resources Questionnaire developed by Bakker (2014) was distributed to full-time academic staff members across the six faculties. This is a structured questionnaire developed to measure all the variables included in the JD-R Model of work engagement however the focus for this study was on job demands and its influence work engagement. The first part of the questionnaire was utilized to determine demographic information on aspects of gender, age, level of education, name of department, tenure, and supervision, amongst others. The second part of the questionnaire dealt with aspects of work engagement and job demands. Job demands were specifically measured by work pressure, cognitive demands, emotional demands, role conflict, and hassles.

\section{Validity and Reliability}

Reliability has to do with the outcomes of the research and relates to the integrity of the findings. It, therefore, refers to the extent to which the findings may be generalized to different measurement occasions or measurements. The validity, on the other hand, refers to the extent 
to which the findings accurately signify what is really happening in the situation (Welman et al., 2012). The JD-R scale reported good internal consistency coefficients of .943 for engagement levels for this study, a pilot study was conducted with 8 participants from the Human Resources Section at NUST. From the responses received, it was clear that respondents understood the questions and no ambiguities were reported. Based on the outcome of the pilot study, no amendments were made to the original questionnaire.

\section{Data Analysis}

Descriptive statistics of mean and standard deviation and inferential statistics of chi-square were done to determine the explanation and association of job demand and work engagement for academic staff at NUST.

\section{Findings}

The main aim of this research was to evaluate the effect of job demands on academic work engagement. A total response rate of $52 \%$ was obtained from a sample of 201 academics.

\section{The Scopes of Job Demand and Work Situation}

This section presents the findings and discussions regarding the impact of job demands on the work engagement levels of academics in relation to their work situation. Responses on questions related to required work speed, work overload, deadlines, time pressure, concentration, and constant attention are provided.

Table 1: Scopes of the Work Situation and Job Demands

\begin{tabular}{|l|c|c|c|}
\hline Scopes of the work situation & Sample size & \multirow{2}{*}{ Mean } & Std Deviation \\
\cline { 2 - 2 } and job demand & $\mathbf{N}$ & & \\
\hline Speed & 210 & 3.27 & 1.184 \\
\hline Work overload & 210 & 3.64 & 1.263 \\
\hline Deadline & 210 & 3.61 & 1.302 \\
\hline Time pressure & 210 & 3.46 & 1.282 \\
\hline Concentration & 210 & 4.12 & 1.051 \\
\hline Precision & 210 & 3.96 & 1.062 \\
\hline Mentally straining & 210 & 3.53 & 1.227 \\
\hline Constant attention & 210 & 4.03 & 0.961 \\
\hline
\end{tabular}

Work situation and job demand variables are measured on a six-point scale using central tendency statistics of mean and standard deviation. Considering a mean of 3.5 as a cut-off point, the academics considered concentration at mean of 4.12, standard deviation score of 1.051; constant attention with the mean of 4.03, deviation score of 0.96 ; precision at mean of 3.96, deviation score of 1.06, workload at mean of 3.64, deviation score of 1.26 and deadline at a mean of 3.61, deviation score of 1.30 as often and very often links work situation and job demand; thus inferring that work situation influences job demand. The mean and standard deviation of the remaining job situation and job demand at 3.00 and deviation score of 1.00 regularly links work situation to job demand. 
INTERNATIONAL JOURNAL OF ACADEMIC RESEARCH IN BUSINESS AND SOCIAL SCIENCES

Vol. 9, No. 10, October, 2019, E-ISSN: 2222-6990 @ 2019 HRMARS

Work Engagement and Emotions at Work

Table 2: Emotions at work

\begin{tabular}{|l|c|c|c|}
\hline Emotions at work & Sample size & Mean & Std Deviation \\
\hline Emotionally demanding & 210 & 3.24 & 1.261 \\
\hline Personally touched & 210 & 3.04 & 1.317 \\
\hline Emotionally charged situations & 210 & 2.78 & 1.349 \\
\hline Client complains & 210 & 3.00 & 1.326 \\
\hline Demanding clients & 210 & 3.04 & 1.382 \\
\hline Client respect & 210 & 2.41 & 1.215 \\
\hline
\end{tabular}

Table 2 exhibits the job engagement and emotions at work. At the mean of 3.00 and standard deviation of 1.3 on emotionally demanding, personally touched, Emotionally charged situations, Client complains and Demanding clients shows that the participants regard emotional engagement at work as regularly compared to the mean of 2.41 and standard deviation score of 1.2 on client respect which was sometimes inferring that emotions at work do not explain work engagement.

Table 3: Conflicting Expectations

\begin{tabular}{|l|c|c|c|}
\hline Conflicting expectation & Sample size & Mean & Std Deviation \\
\hline Conflicting request & 210 & 2.47 & 1.119 \\
\hline Conflicting expectations & 210 & 2.39 & 1.161 \\
\hline Colleague conflict expectations & 210 & 2.40 & 1.104 \\
\hline Opposite expectations & 210 & 2.54 & 1.175 \\
\hline
\end{tabular}

Regarding work engagement and conflict expectations depicted in table 3, results show a mean score of 2.00 and a standard deviation of 1.00 which are below the mean score of 3.50. implying that conflicting request, conflicting expectations, colleague and conflict expectations explains academics level of work engagement. The opposite expectations variable which has a mean score of 2.54 and deviation score of 1.1 sometimes explains academics work engagement.

Job Demand and Work Engagement: Hassles

Table 4: Hassles

\begin{tabular}{|l|c|c|c|}
\hline Hassles & Sample size & Mean & Std Deviation \\
\hline Administrative hassles & 35.5 & 3.81 & 1.191 \\
\hline Project hassles & 22.6 & 3.44 & 1.184 \\
\hline Red tape & 19.4 & 3.20 & 1.290 \\
\hline Unexpected hassles & 20.4 & 3.30 & 1.300 \\
\hline Work hassles & 22.6 & 3.25 & 1.332 \\
\hline
\end{tabular}

The results on work engagement and different hassles portrayed in table 4 show a mean of 3.81 and deviation score of 1.19 implying that academics very often are engaged with administrative hassles. The remaining variables; project hassles with mean of 3.44 and deviation score of 1.18; red tape hassles mean 3.20 and score of 1.29; unexpected hassles mane of 3.30 and score of 1.30 
INTERNATIONAL JOURNAL OF ACADEMIC RESEARCH IN BUSINESS AND SOCIAL SCIENCES

Vol. 9, No. 10, October, 2019, E-ISSN: 222 2-6990 @ 2019 HRMARS

and work hassles mean of 3.25 and deviation score of 1.33 regularly had hassles at work. This implies that work engagement regularly amounts to hassle.

Table 7. Correlation of Job Demands on Engagement Levels

\begin{tabular}{|l|c|c|c|}
\hline \multirow{2}{*}{} & \multicolumn{3}{|c|}{ Correlations } \\
\hline \multirow{2}{*}{ Engagement Levels } & $\begin{array}{c}\text { Engagement } \\
\text { Levels }\end{array}$ & $\begin{array}{c}\text { Job demands (work } \\
\text { situations and emotions) }\end{array}$ \\
\cline { 2 - 4 } & Pearson Correlation & 1 & $-.290^{* *}$ \\
\cline { 2 - 4 } & Sig. (2-tailed & & 0.005 \\
\hline \multirow{2}{*}{$\begin{array}{l}\text { Job demands (work } \\
\text { situations and emotions }\end{array}$} & Pearson Correlation & $-.290^{* *}$ & 93 \\
\cline { 2 - 4 } & Sig. (2-tailed & 0.005 & 1 \\
\cline { 2 - 4 } & $\mathrm{N}$ & 93 & 93 \\
\hline
\end{tabular}

Regarding engagement levels and job demand, the results show a weak negative relationship between engagement levels of academic faculty and work situations and emotions (Pearson correlation, $r=-0.290 ; p=0.005)$. the findings imply that there is no relationship between job demand and work engagement.

\begin{tabular}{|c|c|c|c|}
\hline \multicolumn{4}{|c|}{ Correlation } \\
\hline & & $\begin{array}{l}\text { Engagement } \\
\text { Levels }\end{array}$ & $\begin{array}{l}\text { Job demands (conflict } \\
\text { expectations and hassles) }\end{array}$ \\
\hline \multirow[t]{3}{*}{$\begin{array}{l}\text { Engagement } \\
\text { Levels }\end{array}$} & $\begin{array}{r}\text { Pearson } \\
\text { Correlation }\end{array}$ & 1 & $-.318^{* *}$ \\
\hline & $\begin{array}{l}\text { Sig. } \\
\text { tailed })\end{array}$ & & 0.002 \\
\hline & $\mathrm{N}$ & 93 & 93 \\
\hline \multirow{3}{*}{$\begin{array}{l}\text { Job demands } \\
\text { (conflict } \\
\text { expectations and } \\
\text { hassles) }\end{array}$} & $\begin{array}{l}\text { Pearson } \\
\text { Correlation }\end{array}$ & $-.318^{* *}$ & 1 \\
\hline & $\begin{array}{l}\text { Sig. } \\
\text { tailed })\end{array}$ & 0.002 & \\
\hline & $\mathrm{N}$ & & 93 \\
\hline
\end{tabular}

There exists a weak negative relationship between engagement levels of academic faculty at NUST and conflicting expectations and hassles, $(r=-0.318 ; p=0.002)$. The results portray a weak negative relationship which means engagement does not depend on work situations, emotions, conflicting expectations and hassles.

\section{Hypothesis Testing}

The following hypotheses were tested individually using a Chi-square test. 
INTERNATIONAL JOURNAL OF ACADEMIC RESEARCH IN BUSINESS AND SOCIAL SCIENCES Vol. 9, No. 10, October, 2019, E-ISSN: 2222-6990 @ 2019 HRMARS

Table 5. Work Engagement and Job Demand (work situations and emotions)

\begin{tabular}{|l|c|c|c|}
\hline \multicolumn{4}{|c|}{ Chi-Square Tests } \\
\hline & Value & Df & Asymptotic Significance (2-sided) \\
\hline Pearson Chi-Square & $32.064^{\mathrm{a}}$ & 12 & 0.001 \\
\hline Likelihood Ratio & 30.059 & 12 & 0.003 \\
\hline Linear-by-Linear Association & 7.743 & 1 & 0.005 \\
\hline N of Valid Cases & 93 & & \\
\hline
\end{tabular}

The chi-square results in table 5 show that there was a significant association between job demands on work situations and emotions and work engagement levels of academic faculty at NUST $\left(x^{2}=32.064, d f=12, p=0.001\right)$. On this basis, the null hypothesis is rejected and thus conclude that job demands of work situations and emotions have an impact on engagement levels on the academics.

Table 6. Work Engagement and Job Demand (conflict expectations and hassles)

\begin{tabular}{|l|c|c|c|}
\hline & Value & $\mathrm{df}$ & Asymptotic Significance (2-sided) \\
\hline Pearson Chi-Square & $27.130^{\mathrm{a}}$ & 16 & 0.040 \\
\hline Likelihood Ratio & 29.727 & 16 & 0.019 \\
\hline Linear-by-Linear Association & 9.279 & 1 & 0.002 \\
\hline N of Valid Cases & 93 & & \\
\hline
\end{tabular}

The chi-square results in table 6 show that there was a significant association between job demands (conflict expectations and hassles) and work engagement levels of academic faculty at NUST $\left(x^{2}=27.130, \mathrm{df}=16, p=0.040\right)$. Thus, rejecting the null hypothesis and accept the alternative hypothesis that job demand affects academics work engagement. The findings imply that job demand is associated with work engagement.

\section{Discussion of Results}

Research carried out by Bezuidenhout and Bezuidenhout (2014) allude to challenges in the higher education system such as globalisation of the higher education system, digital transformation in both contact and distance learning institutions, a shortage of academics with doctoral degrees and the increased use of social media in education. These challenges increase job demand and so is the academics work engagement.

Previous studies indicate the detrimental impact of high job demands on work engagement. Rothmann and Joubert (2007) report on job demands and the work engagement of managers at a mine in South Africa revealed that high job demands and lack of work engagement increased levels of burnout. Bezuidenhout and Bezuidenhout, 2007 \& Barkhuizen et al., 2014) reported significant differences in the engagement levels of academics in terms of biographical differences such as gender, educational qualifications, and tenure. 
It was evident that job demand and work engagement were positively correlated. These results support the assumptions of the JD-R Model. The model postulates that job resources predict task enjoyment and organizational commitment, specifically under conditions of high job demands. There is thus a need for stimulus in the form of challenging working conditions, for job resources to be converted into task enjoyment and work engagement (Demerouti \& Bakker, 2011). Furthermore, academics are confronted with high job demands in terms of the increased number of students and demands for academic support. Academics that experience higher job demands on their time, attention and energy, run a higher risk of becoming more exhausted and indifferent in their work lives. This finding tally to Barkhuizen, Rothmann, and Vijver (2013) conception that works engagement results into burnout effect of academics.

Work engagement, specifically the work situations and emotions, have an impact on the engagement levels of the academic staff. This conception is in line with research Barkhuizen, Rothmann and van der Vijver (2013) findings on burnout and works engagement of academics in higher education institutions postulating that exhaustion and burnout are a direct response to job demands and work engagement. Furthermore, academics that experience high levels of job demands are likely to develop high levels of burnout and more likely less work engagement. Thus, academics in higher education institutions are likely to become victims of burnout when there is an increase in job demands. Opposing findings are evident. Coetzer and Rothmann (2008) postulate that job demands are not significantly related to work engagement. Their findings indicated that job demands such as work pace, quantitative and emotional workload, did not play a significant role in the work engagement of participants. Thus, higher work engagement depends on provision of job resources and less likely on job demands.

\section{Conclusions and Recommendations}

This study accounts that job demands, and work engagement specifically the work situations and emotions at the tertiary institution, have an impact on the engagement levels of the academic staff. Since high job demands are directly linked to burnout, it is recommended that the institution develop intervention strategies specifically on academics' work engagement related factors of work situation and coping strategies.

Boyd, Bakker, Pignata, Winefield, Gillespie, and Stough (2011), contends that management of universities can minimise job strain and increase organisational commitment among academics by instigating and upholding rigorous and fair human resource processes. Considerable, in this matter, performance appraisal, promotion, appointment and redundancy procedures, creating an open climate for communication and adequately consulting staff about changes in their workplace and actively protecting and encouraging the autonomy of academics to make their own decisions, use their initiative, and function semi-autonomously from management in their day-to-day work affects job demand and work engagement of academics.

This study did not investigate these dimensions and how job demands may differ in terms of the above -mentioned demographics. As such future research in this regard is recommended. It is furthermore recommended that the part-time and administrative staff of NUST be included in a similar study. Lastly, it is advised that a study on work engagement and its antecedents, especially job demands, be extended to other institutions of higher learning in Namibia. 
INTERNATIONAL JOURNAL OF ACADEMIC RESEARCH IN BUSINESS AND SOCIAL SCIENCES

Vol. 9, No. 10, October, 2019, E-ISSN: 2222-6990 @ 2019 HRMARS

\section{References}

Arokiasamy, L., Ismail, M., Ahmad, A., \& Othman, J. (2009). Background Of Malaysian Private Institutions Of Higher Learning And Challenges Faced By Academics. Journal of International Social Research, 2(8).

Bakker, A. B., Van Veldhoven, M., \& Xanthopoulou, D. (2010). Beyond the demand-control model. Journal of Personnel Psychology.

Barkhuizen, N., Rothmann, S., \& Vijver, F. J. (2014). Burnout and work engagement of academics in higher education institutions: Effects of dispositional optimism. Stress and Health, 30(4), 322-332.

Bezuidenhout, A., \& Bezuidenhout, G. (2014). Work engagement in female academics at an open distance learning and a contact university in South Africa: Review and critique. Mediterranean Journal of Social Sciences, 5 (7), 324-332. doi:10.5901/2014v5n7p324

Boyd, C. M., Bakker, A. B., Pignata, S., Winefield, A. H., Gillespie, N., \& Stough, C. (2011). A longitudinal test of the job demands-resources model among Australian university academics. Applied psychology, 60(1), 112-140.

Coetzer, C. F., \& Rothmann, S. (2007). Job demands, job resources and work engagement of employees in a manufacturing organisation. Southern African Business Review, 11(3), 1732.

Demerouti, E., \& Bakker, A. B. (2011). The job demands-resources model: Challenges for future research. SA Journal of Industrial Psychology, 37(2), 01-09.

Denscombe, M. (2010). The good research guide for small -scale social research projects (4th ed.). New York, NY: McGraw Hill Open University Press.

Kotzé, T. (2011). Theme 3: What is research? Unpublished Course Notes: EBW 801 (pp. 1 - 15). Pretoria: University of Pretoria.

Neuman, W. L. (2011). Social Research Methods: Qualitative and Quantitative Approaches: (7 $7^{\text {th }}$ ed). Boston, MA: Pearson Education.

Rothmann, I., \& Cooper, C.L. (2015). Work and organisational psychology :( 2nd ed). New York, NY: Routledge

Rothmann, S., \& Jordaan, G. M. E. (2006). Job demands, job resources and work engagement of academic staff in South African higher education institutions. SA Journal of Industrial Psychology, 32(4), 87-96.

Schaufeli, W., \& Bakker, A. (2003). UWES Utrecht Work Engagement Scale: Preliminary Manuel, Occupational Health Psychology Unit. Utrecht University.

Sedgwick, P. (2014). Cross sectional studies: advantages and disadvantages. BMJ: British Medical Journal, 348.

Strydom, M., Mostert, K., \& Rothmann, S. (2006). A psychometric evaluation of the job demands-resources scale in South Africa. SA Journal of Industrial Psychology, 32(4), 76 86.

Welman, C., Kruger, F., \& Mitchell, B. (2012). Research Methodology: (3 ${ }^{\text {rd }}$ ed.). Cape Town, South Africa: Oxford University Press. 